\title{
As formas de vida consagrada na Amazônia
}

Consecrated forms of life on Amazon

No início do Cristianismo, causava espanto a forma como os cristãos ofereciam comida e assistência aos que precisavam de ajuda, socorrendo-os sem qualquer discriminação; muitos questionavam que tipo de religião era aquela, que podia inspirar tais atos de generosidade e humanidade 2 . São Paulo, na Carta aos Gálatas ${ }^{3}$, afirmou que os cuidados e a caridade dos cristãos deveriam ser dados a todos, ainda que fossem inimigos da fé. Nesse sentido, a Igreja primitiva promoveu a caridade e institucionalizou a atenção às viúvas, aos órfãos e aos enfermos. Muitos mosteiros tornaram-se prestadores de serviços médicos; eram locais que favoreciam a cura, a piedade e a estabilidade.

\footnotetext{
1 Advogada atuante no escritório Almeida \& Neckel Advocacia e Consultoria Jurídica nas áreas de Direito Canônico e Religioso, Direito Civil e Direito Penal. Especialista em Direito Penal, Processo Penal e Direito Processual Civil. Mestranda em Direito Canônico no Instituto Superior de Direito Canônico Santa Catarina ISDC/SC, agregado à Pontifícia Universidade Lateranense de Roma. Membro da Sociedade Brasileira de Canonistas - SBC e do Instituto Brasileiro de Direito e Religião - IBDR. Juíza instrutora da Câmara Eclesiástica e integrante da Comissão Diocesana para a proteção de Menores e Pessoas em estado de vulnerabilidade da Diocese de Rio do Sul - SC. E-mail: neckel.silvana@gmail.com.

2 THOMAS E. WOODS JR. Como a Igreja Católica construiu a civilização ocidental. $9^{a}$ ed. São Paulo: Editora Quadrante, 2014, p. 159.

${ }^{3}$ BÍBLIA DE JERUSALÉM, Gálatas, 6,10.
} 
São Basílio Magno, o Apóstolo das Esmolas, era conhecido por abraçar os leprosos miseráveis que ali buscavam alívio à sua doença. Os beneditinos, os cistercienses e os premonstratenses e, mais tarde, as ordens mendicantes, os franciscanos e os dominicanos distinguiram-se pela dedicação às obras de caridade com os cristãos e os pagãos ${ }^{4}$.

Assim, desde o início da Igreja, inúmeros homens e mulheres decidiram seguir a Cristo e imitá-lo, praticando seus ensinamentos, e, cada um a seu modo, viveu uma vida consagrada a Deus; alguns de forma solitária, outros fundaram grupos religiosos organizados com o mesmo carisma recebido pelo Espírito Santo. A Igreja Católica criou a prática das obras de caridade e, até os dias de hoje, promove a justiça social, auxiliando o povo de Deus, por meio de sua estrutura institucional e normativa da vida consagrada, que se apresenta em diversas formas na legislação eclesiástica.

A partir do Código de Direito Canônico e da Exortação Apostólica de São João Paulo II Vita Consecrata, estão configuradas, na normativa, as formas desse estado de vida eclesial. A Igreja recebeu essas diversas formas de vida consagrada e aprovou seu apostolado, pelo qual o fiel assume livremente essa forma de vida nos institutos, canonicamente erigidos pela autoridade competente da Igreja, por meio dos votos ou de outros vínculos sagrados, e, conforme as leis próprias dos institutos, professam os conselhos evangélicos de castidade, pobreza, obediência e, pela caridade, unem-se de modo especial à Igreja ${ }^{5}$. São João Paulo $\mathrm{II}^{6}$ ressalta que o chamado à vida consagrada é um dom específico do Espírito Santo a alguns do povo de Deus, em vista da edificação da Igreja e da salvação do mundo. Há muitos institutos de vida consagrada na Igreja, com diversos dons, segundo a graça que lhes foi dada, pois seguem mais de perto a Cristo,

\footnotetext{
${ }^{4}$ Op. cit., p. 174.

5 JOÃO PAULO II. Codex Iuris Canonici (CIC-1983), promulgado pela Constitutione Apostolica Sacrae disciplinae leges. In: AAS 75, 1983, cânon 573, §2.

${ }^{6}$ JOÃO PAULO II. Exortação apostólica pós-sinodal Vida Consagrada: sobre a vida consagrada e a sua missão na Igreja e no mundo, 25 mar. 1996. In: AAS 88, 1996, 377-486, n. 30.
} 
que anuncia o Reino de Deus, que faz o bem aos homens, que convive com eles no mundo, cumprindo sempre a vontade do $\mathrm{Pai}^{7}$.

Entre as formas de vida consagrada, temos os institutos religiosos, e dentre esses, os mosteiros e os cônegos regulares; seus membros vivem em fraternidade, na qual o grupo de pessoas forma uma comunidade que implica utilizar o mesmo caminho de conversão, na mesma regra de vida, conforme o carisma e as constituições, buscando o bem presente e a salvação ${ }^{8}$. Também a vida eremítica ou anacorética, pela qual os fiéis por meio do afastamento estrito do mundo, do silêncio na solidão, da oração assídua e da penitência, consagram a sua vida ao louvor de Deus e à salvação do mundo ${ }^{9}$. A Igreja também reconhece a ordem das virgens, as quais, emitindo o santo propósito de seguir mais de perto a Cristo, são consagradas a Deus pelo bispo diocesano, e dedicam-se ao serviço da Igreja $^{10}$. Há também na Igreja o instituto secular, em que os fiéis, vivendo no século, esforçam-se por atingir a perfeição da caridade e por contribuir para a santificação do mundo ${ }^{11}$. Assemelham-se aos institutos de vida consagrada as sociedades de vida apostólica, cujos membros, sem votos religiosos, prosseguem o fim apostólico próprio da sociedade e, vivendo em comum a vida fraterna, de acordo com a própria forma de vida, tendem, pela observância das constituições, à perfeição da caridade.

Após o Concílio Ecumênico Vaticano II, surgiram novas formas de vida consagrada, com novos estímulos espirituais e apostólicos, constituídas por homens e mulheres, clérigos e leigos que seguem um estilo particular de vida adaptados à exigência atual, com tendência à intensa vida comunitária, à pobreza, à oração de adoração ao Santíssimo Sacramento. São novos dons de vida consagrada confiados pelo Espírito Santo à Igreja, e cabe aos bispos

${ }^{7}$ CIC-1983, cânon 577 .

8 DENILSON, Geraldo. A vida consagrada no código de direito canônico. Aparecida: Editora Santuário, 2012, p. 43.

${ }^{9}$ Op. cit., cânon 603,1 .

${ }^{10}$ Ibid., cânon 604, §1, §2.

${ }^{11}$ Ibid., cânon 710 . 
discernirem o seu carisma e reconhecer seus traços específicos fundados sobre elementos essenciais, teológicos e canônicos, próprios da vida consagrada ${ }^{12}$.

Recentemente, o Papa Francisco publicou a Exortação Apostólica Pós-Sinodal "Querida Amazônia" e chamou a atenção para os problemas da região amazônica ${ }^{13}$. Apontou as dificuldades enfrentadas pela Igreja na evangelização dos povos amazônicos e lembrou-se das muitas pessoas consagradas que gastaram as suas energias e grande parte da sua vida pelo Reino de Deus na Amazônia. Destacou, ainda, que a vida consagrada, capaz de diálogo, síntese, encarnação e profecia, ocupa um lugar especial nessa configuração plural e harmoniosa da Igreja amazônica, mas lhes faz falta um novo esforço de inculturação, que ponha em jogo a criatividade, a audácia missionária, a sensibilidade e a força peculiar da vida comunitária ${ }^{14}$.

Nesse sentido, a vida consagrada pode contribuir para a evangelização na Amazônia, pois é capaz de adaptar-se às várias realidades e configurar-se a partir das necessidades das regiões em que vivem seu apostolado. No entanto, para isso, devem manter-se fiel à intenção e aos propósitos dos fundadores sobre a natureza, fim, espírito e índole do instituto, bem como às suas tradições, pois tudo isso constitui o patrimônio desses institutos de vida consagrada ${ }^{15}$.

Diante de sua relevância, esses institutos são erigidos pelos bispos diocesanos, em seu respectivo território, após consulta a Sé Apostólica ${ }^{16}$; contudo, na falta de dioceses na região amazônica e a necessidade do apostolado da vida consagrada naquela região, pode o Sumo Pontífice isentar os institutos de vida consagrada da autoridade dos Ordinários do lugar e subordiná-los,

\footnotetext{
${ }^{12}$ DENILSON, Geraldo. As formas de vida consagrada como dom do Espírito Santo à Igreja. In: REVISTA DE CULTURA TEOLÓGICA, v.19, n. 74, abr.jun. 2011, p. 106.

${ }^{13}$ FRANCISCO. Exortação Apostólica Pós-Sinodal “Querida Amazônia”, 02 fev. 2020, n. 5.

${ }^{14}$ Ibid., n. 95.

${ }^{15}$ CIC-1983, cânon 578.

${ }^{16}$ Ibid., cânon 579 .
} 
exclusivamente, a si mesmo ou a outra autoridade eclesiástica ${ }^{17}$. Assim, a fim de facilitar o apostolado $^{18}$ dos institutos e uma concreta possibilidade de inculturação dos povos amazônicos, poderá haver a agregação dos institutos; a sua divisão em partes; a ereção de novas partes, a supressão e também a fusão e a união de institutos de vida consagrada ${ }^{19}$.

\footnotetext{
${ }^{17}$ Ibid., cânon 591.

${ }^{18}$ Ibid., cânon 673 - O apostolado de todos os religiosos consiste em primeiro lugar no testemunho da sua vida consagrada que estão obrigados a fomentar com a oração e a penitência.

${ }^{19}$ Ibid., cânones 580, 581, 582, 584.
} 